\title{
The effects of pollen availability during larval development on the behaviour and physiology of spring-reared honey bee workers*
}

\author{
Heather R. MATTILA, Gard W. OTIS \\ Department of Environmental Biology, University of Guelph, Guelph, ON, Canada, N1G 2W1
}

Received 18 September 2005 - Revised 16 December 2005 - Accepted 20 December 2005

\begin{abstract}
Over two years, we investigated the effects of altering the availability of pollen in colonies during the spring on the physiology, longevity and division of labour of spring-reared workers. In the first year, workers reared in colonies supplemented with pollen were longer-lived but lighter and less protein-rich at emergence than workers reared in colonies with limited pollen supplies. In the second year, patterns were different and workers reared in colonies with pollen supplements were shortest-lived but similar physiologically to workers from colonies with less pollen. As adults, these workers also spent more time tending brood, less time patrolling or resting idly on the comb and were less likely to participate in foraging than workers reared in pollen-limited colonies. The availability of pollen during larval development influenced worker traits, but variability in response across years is also attributable to other environmental factors that were not controlled in these studies.
\end{abstract}

Apis mellifera / pollen / nursing / division of labour / worker quality

\section{INTRODUCTION}

In cold temperate climates, honey bee (Apis mellifera L.) colonies rely on the production of spring-reared workers to rebuild the aging winter population. At this time, the colony is composed of "winter bees" that were reared during the previous fall before brood rearing was suspended (Fukuda and Sekiguchi, 1966; Mattila et al., 2001). These winter bees use the nutritional reserves stored in their bodies (Haydak, 1935; Fluri et al., 1982) and the cache of pollen that was accumulated in the colony during the fall (Farrar, 1936) to begin rearing brood within the cluster in early

Corresponding author: H.R. Mattila,

hrm24@cornell.edu (primary);

heathermattila@gmail.com (secondary)

Present address: Department of Neurobiology and Behavior, Cornell University, Ithaca, NY, 14853, USA.

* Manuscript editor: Stan Schneider spring. Pollen is the only dietary source of protein, lipids, vitamins and minerals for the nutrition of developing larvae (reviewed by Herbert, 1992). It is fed to larvae directly or as nutrient-rich brood food produced by the nurses that consume pollen (reviewed by Crailsheim, 1990).

Pollen stores in colonies often become depleted during the spring before more resources can be gathered in the environment (Farrar, 1934). Even as foraging opportunities increase in frequency, periods of inclement weather can disrupt pollen intake for several days, inducing brood cannibalism as workers run low on pollen reserves (Dustmann and Von der Ohe, 1988; Schmickl and Crailsheim, 2001). We have recently suggested in a three-year study that colonies tailor worker production to pollen supply in the spring (Mattila and Otis, 2006). Depending on annual conditions, colonies that received additional pollen or pollen substitutes during the spring produced 
between 5900 to 18500 more workers per colony by May compared to colonies that had their winter pollen reserves artificially reduced (Mattila and Otis, 2006). It is clear that increasing the pollen supply in colonies resulted in the production of more workers, but it is not known if improved pollen diet was also reflected in the quality of the workers reared in these colonies. The purpose of this study is to quantify the accompanying effects of pollen availability on the behaviour and physiology of workers that were reared during the spring in these colonies. We report two years of data on the effects of spring pollen supply on worker longevity, dry weight, protein content and in-hive task performance and foraging patterns.

Worker quality can be evaluated by several indicators, but the most commonly cited measure is longevity. Previous research has demonstrated that worker longevity is inversely correlated with the amount of brood that is present in colonies and is regulated by the nursing load on workers (Maurizio, 1950; Fukuda and Sekiguchi, 1966; Neukirch, 1982; Amdam and Omholt, 2002). Once workers begin nursing, they have a high demand for pollen-derived nutrients to support brood-rearing physiology. Consequently, the amount of pollen available to workers has an enormous influence on the length of time that they can continue to nurse (Maurizio, 1950, 1954, 1959). Protein-stressed workers have depressed hypopharyngeal gland development, reduced nursing activity and accelerated onset of foraging compared to workers that receive adequate nutrition (Free, 1961; Wang and Moeller, 1970). For these reasons, worker longevity, nursing activity and foraging patterns were used as important measures of worker quality in this study because they are so intimately tied to the pollen status of colonies.

Quality can also be estimated by the weight of workers or the size of their nutrient reserves at adult emergence. Each measure provides an accurate indication of nutritional investment during the larval stage and can be influenced by the availability of food resources in colonies. Eischen et al. (1982) showed that worker dry weight and longevity increased when workers were reared by a greater number of nurses, which they attributed to increased nutritional investment per larva. Levin and Haydak (1951) found that larger colonies tended to rear heavier workers than smaller colonies and that this trend fluctuated seasonally with pollen income. At emergence, bees that are long-lived and survive over the winter have greater dry weights and protein and fat contents than shorter-lived workers reared during other seasons (Kunert and Crailsheim, 1988). Conversely, artificially induced malnutrition results in the production of undersized workers (Alpatov, 1929; Fyg, 1959; Jay, 1964; Daly et al., 1995). Schmickl and Crailsheim (2001) found that colonies experiencing pollen shortages produced workers that had slightly reduced levels of protein. Inadequate pollen diet can lower worker nitrogen content (Duff and Furgala, 1986, although effects were lacking in some years) and result in shorter lifespans for nurses and their progeny (Eischen et al., 1982; Kulinĉević et al., 1983). In general, the relationship between worker size, protein content and longevity suggests that more nutrient-rich workers are larger and longer lived. All of this evidence clearly supports a robust association between pollen diet and worker quality with respect to longevity, size and protein content, although many of these studies were conducted under artificial conditions. For this reason, it is not clear if the same effects on worker weights and protein levels would be observed in honey bee colonies as they make adjustments to worker production under more natural circumstances.

In colonies during the spring, food resources are distributed between the dual demands of providing each colony member with adequate nutrients for development and the production of as many workers as possible so that population growth is maximized. It is apparent that colonies respond to the availability of pollen by adjusting the number of workers that are reared (Mattila and Otis, 2006). At this time, there is little information on how the distribution of resources is reflected in individual workers. Over two years, this study examined the behavioural and physiological traits of workers reared by colonies that have been supplemented with or deprived of pollen during 
spring brood rearing. Our findings highlight the important role that pollen supply plays in the determination of worker function during the spring, in conjunction with other environmental factors specific to each year.

\section{MATERIALS AND METHODS}

The study was conducted in spring 2002 and 2003 in Guelph, Ontario, Canada. Each year, a new set of colonies was selected in the fall preceding the spring study and colonies were randomly assigned to a pollen treatment. Each colony consisted of a full-sized Langstroth hive body for a brood chamber and was headed by a lab-reared and naturally mated queen of mixed Buckfast and Italian descent. Genotype, which can have a significant influence on pollen foraging, storage and utilisation in colonies (e.g., Hellmich et al., 1985; Calderone and Page, 1992; Dreller and Page, 1999), was not controlled for in this study so that natural variation in colony response across treatment groups would be quantified. Each spring, a four-frame nucleus colony was installed in a glass-walled observation hive that was housed in a building located $1200 \mathrm{~m}$ from the field colonies in 2002 and $30 \mathrm{~m}$ away in 2003.

\subsection{Manipulating pollen availability during the spring}

The amount of pollen available to colonies during the springs of 2002 and 2003 was manipulated as follows (seven colonies per treatment in both years):

\subsubsection{Pollen-supplemented treatment, spring (both years)}

The pollen diet of colonies was supplemented by feeding pollen patties to colonies during the spring. Patties were $500 \mathrm{~g}$ each and consisted of pollen mixed with liquid sucrose at a 2:1 ratio by weight. The patty mixture was flattened between sheets of waxed paper and placed on the top of the frames over the brood cluster. Pollen feeding began on 8 and 17 March in 2002 and 2003, respectively. Colonies were provided with patties every seven to ten days as they were consumed; each colony received five patties by 18 April in 2002 and four patties by 29 April in 2003 .

\subsubsection{Pollen-supplemented treatment, fall (second year only)}

Patties consistent with those just described were fed to colonies from 14 September to 10 October. Patties were replaced every six to twelve days and four patties were fed to each colony in total.

\subsubsection{Substitute-supplemented treatment, spring (second year only)}

Colonies were fed $500 \mathrm{~g}$ patties made from a dry pollen substitute (Bee-Proß), Mann Lake Limited, Hackensack, USA) mixed with liquid sucrose at a $3: 2$ ratio by weight. Pollen-substitute patties were provided to colonies on the same dates as pollen patties.

\subsubsection{Pollen-limited treatment, preceding fall (both years)}

The availability of pollen in colonies during the spring was limited by trapping pollen from them prior to overwintering. OAC pollen traps were fitted to colonies in late August and were left in place until pollen was no longer available in the environment (October). Pollen traps were emptied every two to three days; the pollen was weighed and then frozen at $-20{ }^{\circ} \mathrm{C}$ until it was used for the pollen-supplemented treatments. An average of $2.1 \pm 0.03$ and $6.2 \pm 0.35 \mathrm{~kg}$ of pollen was trapped from each colony during the first and second years, respectively. Trapping pollen from colonies significantly reduced visible pollen stores in pollenlimited colonies compared to control colonies when the area of comb that contained pollen was compared on 3 October $2001\left(80 \pm 35 \mathrm{~cm}^{2}\right.$ versus $780 \pm 180 \mathrm{~cm}^{2}$ per colony, respectively; $P<0.01$ ).

\subsubsection{Control treatment (both years)}

Colonies were left to collect, store and use pollen naturally.

\subsection{Estimating worker longevity}

All workers were reared in treatment colonies and then introduced into a common observation hive after adult emergence in each year. Newly emerged workers $(<24 \mathrm{~h}$ old) were obtained from each parental colony by placing brood frames overnight in an incubator $\left(34{ }^{\circ} \mathrm{C}\right.$ and $65 \%$ relative humidity). The next morning, workers were marked 
with numbered and coloured tags (Opalithplattchen, Christian Graze KG, Weinstadt-Endersbach, Germany) and introduced into the observation hive on 10 and 18 April in the spring of 2002 and on 29 April in 2003. In 2002, many of the colonies had very little sealed brood on these introduction dates, so the number of marked workers was sometimes low, especially for colonies with limited pollen. In total, 406 marked workers were introduced into the observation hive in 2002 (pollensupplemented treatment: 23 to 35 workers per colony from seven colonies; control treatment: 9 to 51 workers per colony from six colonies; pollenlimited treatment: 5 to 8 workers per colony from two colonies). It was easier to obtain emerging workers in 2003; 500 workers were introduced to the observation hive in that year ( 20 workers from five colonies in each of five treatment groups). The observation hive was scanned each morning after the introduction of the marked workers to record their presence; scans continued until the last marked worker disappeared. The longevity and survivorship of workers from each treatment group were determined from these data in both years.

\subsection{Monitoring behaviour in the observation hive}

The behaviour of marked workers was monitored in the observation hive from 1 May to 4 June in 2003, when workers were 2 to 36 days of age. Each morning, the colony was mapped on a grid ( $5 \times 5 \mathrm{~cm}$ squares) drawn on the glass walls to delineate areas of brood from food and empty space. The grid was scanned from top to bottom once daily in the early morning and the behaviour and location of marked workers were recorded each time they were encountered in a square. This method was modified from the procedure and list of behaviours described by Kolmes (1984). For each cohort of workers (i.e., the group of 20 marked workers from a single parental colony), the proportion of all recorded behaviours that were brood-care related (inspecting or feeding larvae, inspecting an egg or an empty cell in the brood area or "mouthing" sealed brood [worker walks over sealed brood with head and antennae in contact with pupal cappings, rapidly moving her mandibles]) was compared over time between treatments. The proportions of the total number of observations that included walking (moving over comb in any direction at any speed) or resting (inactive on the surface of the comb for longer than five seconds of observation) were also determined for each cohort because these activities occupy much of workers' lives (30\% and $40 \%$ of activity, respectively; Lindauer, 1953). The number of times workers were encountered in brood areas or food areas over the period of observation was also examined.

\subsection{Monitoring foraging patterns}

The foraging activity of marked workers was recorded from 9 May to 3 June in 2003 when workers were 10 to 35 days of age. The entrance of the observation hive was monitored for three hours each morning that weather permitted foraging and marked foragers that were leaving or returning to the observation hive were recorded. From these data, the proportion of the cohort that foraged and the onset and duration (the number of days between the first and last observation at the entrance) of foraging were compared between treatment groups.

\subsection{Measuring dry weight and protein content of workers}

Approximately ten newly emerged workers were collected from each colony on the days when marked workers were introduced into the observation hive in each year (10 and 18 April in 2002 and 29 April in 2003). In 2002, additional samples of workers were collected at adult emergence on 26 April. The workers were frozen at $-70{ }^{\circ} \mathrm{C}$ until they were analyzed for dry weight and protein content. The digestive tract was removed from workers so that gut contents would not confound the results and the bees were subsequently freezedried for 96 hours (Labconco Corp., Kansas City, USA). In 2002, legs and wings were removed from workers for a separate study, so whole body dry weight measurements in this year did not include appendages.

Protein content (mg) was determined for whole bodies in 2002 and for heads and abdomens separately in 2003. Protein levels were assayed using a bicinchoninic acid protein assay kit (Pierce Biotechnology, Inc., Rockford, USA). Standard curves were generated with bovine albumin serum (provided with kit) and $2.0 \mathrm{M} \mathrm{NaOH}$ was used as an extract diluent. Samples were not compared across 2002 and 2003 because of discrepancies between the number of treatment groups and the presence or absence of legs and wings. 

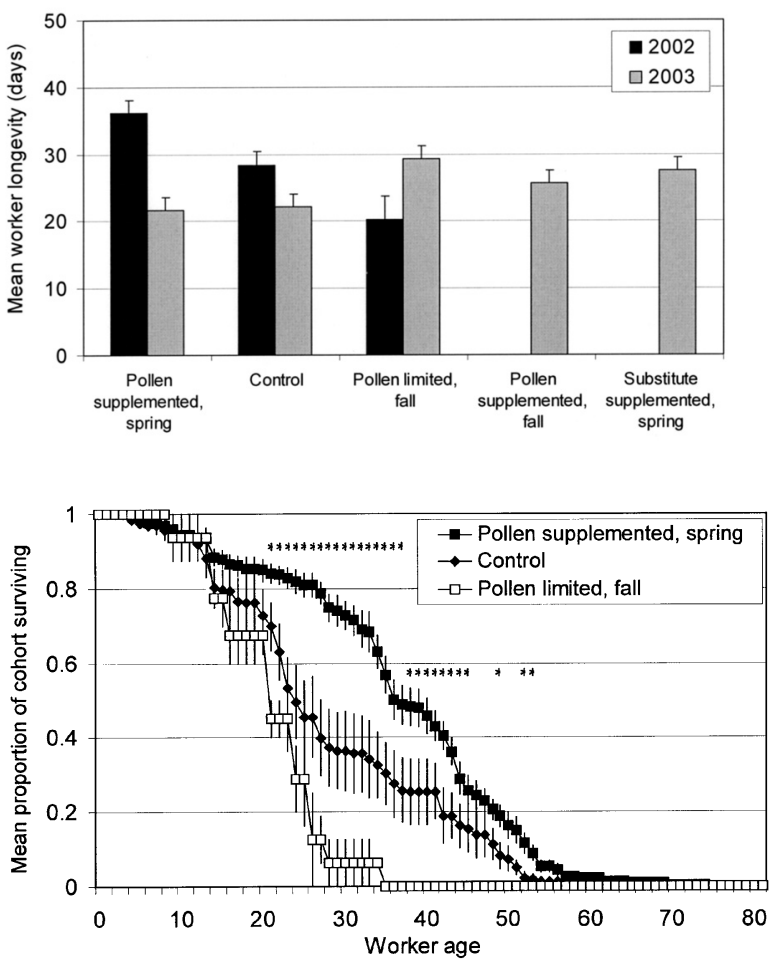

Figure 1. The mean longevity (+ S.E.) of workers reared during spring 2002 and 2003 in pollen-supplemented and pollenlimited colonies. Treatment means within each year were separated by Tukey's studentized range test; differences within each year are indicated by different letters. In 2002: $\mathrm{N}=7$ pollen-supplemented colonies, $\mathrm{N}=6$ control colonies, $\mathrm{N}=2$ pollen-limited colonies. In 2003: $N=5$ colonies per treatment.

\subsection{Statistical analyses}

All statistical analyses were performed with SAS Version 8.2 (SAS Institute Inc., Cary, USA; SAS Institute, 2004). A one-way analysis of variance (ANOVA) for a completely randomized design was used to examine differences among treatment means for each estimate that was measured on colonies or cohorts from colonies (e.g., proportion of behaviours that were related to brood care for each cohort; PROC GLM). For measurements that were made on individual workers (e.g., worker longevity), a mean value was determined for each colony and these means were compared among treatment groups in an ANOVA. When significant treatment effects were detected, means were separated by Tukey's studentized range test. Relationships between the variables examined in 2003 were determined using Pearson's product-moment correlation (PROC CORR). A Bonferroni-Holms stepdown correction was used to adjust $P$ values and to lower the likelihood of a making a Type I error when multiple variables were correlated against the same worker trait. A significance level of $\alpha=0.05$ was used for all tests. Means are reported with standard errors (S.E.).

\section{RESULTS}

\subsection{Worker longevity}

\subsubsection{Spring 2002}

Worker longevity was similar for bees emerging on 10 and 18 April in $2002(P=$ 0.42 ), so these groups were pooled for all analyses. Pollen supply during larval development had a significant impact on worker longevity in this year (Fig. 1; $P<0.01$ ). Workers that were reared in pollen-supplemented colonies lived a mean of 8 days longer than workers reared in control colonies and 16 days longer than workers from pollen-limited colonies, even though all workers shared a common environment as adults (Fig. 1). Survival in 2002 was higher for workers reared with pollen supplements compared to the other treatment groups when workers were between 21 days and 53 days of age (Fig. 2). 

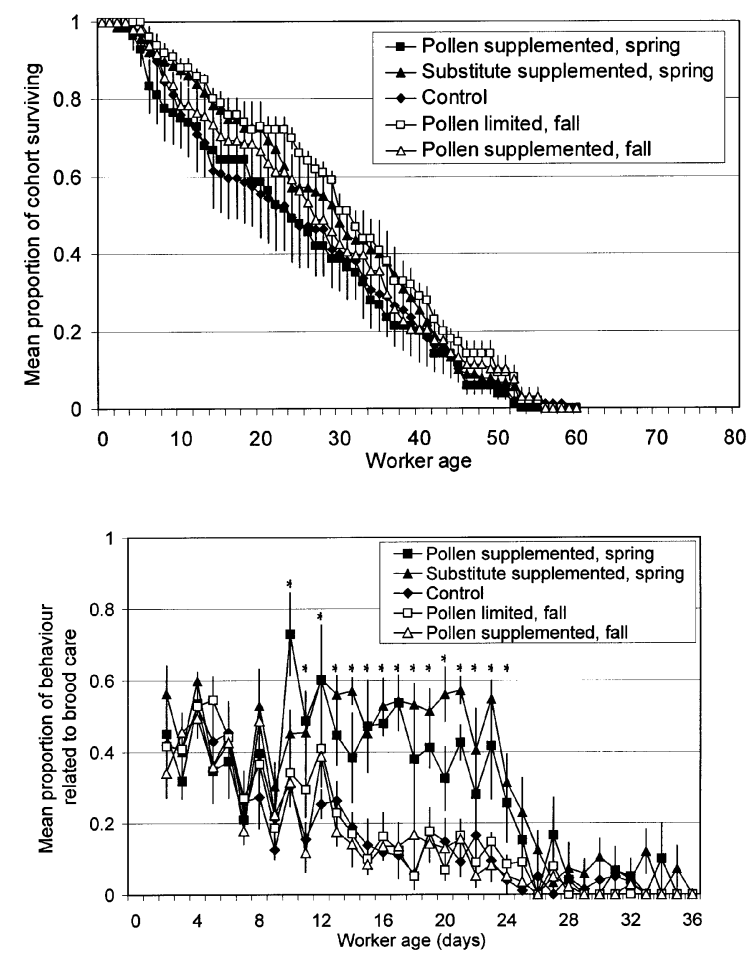

Figure 3. The mean proportion ( \pm S.E.) of workers that survived over time for workers reared in pollen-supplemented or pollenlimited colonies during spring $2003(\mathrm{~N}=5$ colonies per treatment).

Figure 4. The mean proportion ( \pm S.E.) of behaviours that were related to brood care performed over time by cohorts of workers reared in pollen-supplemented or pollenlimited colonies during spring 2003. Pollen availability had a significant effect on the brood-care behaviour demonstrated daily by workers when workers were 10 to 24 days of age (indicated by asterisks; $\mathrm{N}=5$ colonies per treatment).

\subsubsection{Spring 2003}

\subsection{Behaviour in the observation hive}

A total of 9058 behavioural observations were made of marked workers in the observation hive during spring 2003; these were distributed evenly among treatment groups $(P=$ 0.18 ). Pollen supply during larval development had a significant effect on the broodcare behaviour of workers as adults (Fig. 4). Workers that were reared in colonies that were supplemented with pollen during the spring (either with pollen or a pollen substitute) performed brood-related tasks two times more often than workers from control colonies or colonies that had pollen availability manipulated during the fall $(P<0.01)$. When each day was analysed separately, workers reared in colonies that were supplemented in the spring were observed caring for brood more often than workers from colonies with less pollen in the spring from 10 days to 24 days of age (Fig. 4).

Workers reared in colonies with spring supplements were less likely to be seen walking in the colony (without performing other 
Table I. The effect of pollen availability during larval development on aspects of the foraging activity of workers during spring 2003 ( $\mathrm{N}=5$ colonies per treatment). Workers were reared in pollen-supplemented or pollen-limited colonies and were then transferred to a common observation hive at adult emergence. Where effects of treatment were significant, means were separated by Tukey's studentized range test. Differences between means in each column are indicated by different letters.

\begin{tabular}{lcccc}
\hline & $\begin{array}{c}\text { Mean age (d) } \\
\text { at onset } \\
\text { of foraging }\end{array}$ & $\begin{array}{c}\text { Mean proportion } \\
\text { of cohort } \\
\text { that foraged }\end{array}$ & $\begin{array}{c}\text { Mean forager } \\
\text { lifespan (d), } \\
\text { including } \\
\text { non-foragers }\end{array}$ & $\begin{array}{c}\text { Mean forager } \\
\text { lifespan (d), } \\
\text { excluding } \\
\text { non-foragers }\end{array}$ \\
\hline Pollen supplemented, spring & $19.1 \pm 0.7$ & $0.47 \pm 0.06 \mathrm{a}$ & $3.7 \pm 0.72 \mathrm{a}$ & $8.9 \pm 0.86$ \\
Substitute supplemented, spring & $18.2 \pm 0.7$ & $0.72 \pm 0.06 \mathrm{ab}$ & $5.5 \pm 0.72 \mathrm{ab}$ & $8.0 \pm 0.86$ \\
Control & $17.4 \pm 0.7$ & $0.54 \pm 0.06 \mathrm{ab}$ & $5.9 \pm 0.72 \mathrm{ab}$ & $10.9 \pm 0.86$ \\
Pollen limited, fall & $18.1 \pm 0.7$ & $0.70 \pm 0.06 \mathrm{ab}$ & $6.9 \pm 0.72 \mathrm{~b}$ & $9.8 \pm 0.86$ \\
Pollen supplemented, fall & $18.1 \pm 0.7$ & $0.79 \pm 0.06 \mathrm{~b}$ & $7.0 \pm 0.72 \mathrm{~b}$ & $9.1 \pm 0.86$ \\
\hline
\end{tabular}

tasks) compared to workers from other treatments $(P<0.01)$. Of all of the behaviours recorded for a cohort of workers from a single parental colony, $25 \%$ to $27 \%$ included walking for workers reared by colonies that were supplemented in the spring compared to $37 \%$ to $40 \%$ for workers from control colonies or colonies that were treated during the fall. Pollen conditions during rearing also affected the inactivity level of workers (i.e., the proportion of all behavioural acts that included resting on the comb: $P=0.02$ ). Workers reared by colonies supplied with pollensubstitute during the spring were inactive $16 \%$ of the time compared to $27 \%$ of the time for workers reared by colonies that were supplemented with pollen during the fall. Resting behaviour was observed $18 \%$ to $25 \%$ of the time for workers from the remaining treatment groups. Workers were encountered in comparable numbers in the brood area regardless of pollen conditions during rearing $(P=0.17)$. However, workers from colonies that were fed pollen in the fall were two times more likely to be found in areas where food was stored than workers that were reared in colonies that were supplemented with pollen during the spring $(P=0.02)$.

Generally, workers reared in colonies that received spring diet supplements behaved differently in the observation hive compared to workers reared in fall-treated or control colonies. Workers from these latter treatments were behaviourally indistinguishable in all respects.

\subsection{Foraging patterns}

In 2003, the age at which workers initiated foraging was not affected by the availability of pollen during larval development (Tab. I; $P=0.61$ ). The proportion of workers that were observed foraging over the course of the study was lowest for those reared in colonies supplemented with pollen during the spring (Tab. I), although there was no specific day on which the level of foraging differed between pollen treatments (Fig. 5). Workers reared under spring pollen-supplemented conditions foraged at $60 \%$ of the level of workers from colonies that were fed pollen during the fall $(P<0.01)$. This difference is reflected in the mean foraging lifespan of workers in each treatment group; workers reared by colonies supplemented with pollen during the spring foraged for three days less on average than workers from colonies that had pollen availability manipulated during the fall (Tab. I; $P$ $=0.02)$. When the workers that never foraged were excluded from this analysis, the effects of pollen availability on foraging lifespan were lost (Tab. I; $P=0.20$ ). This means that if workers foraged, then there was no difference in when they began to forage or the amount of time that they foraged; however, fewer workers from colonies supplemented with 

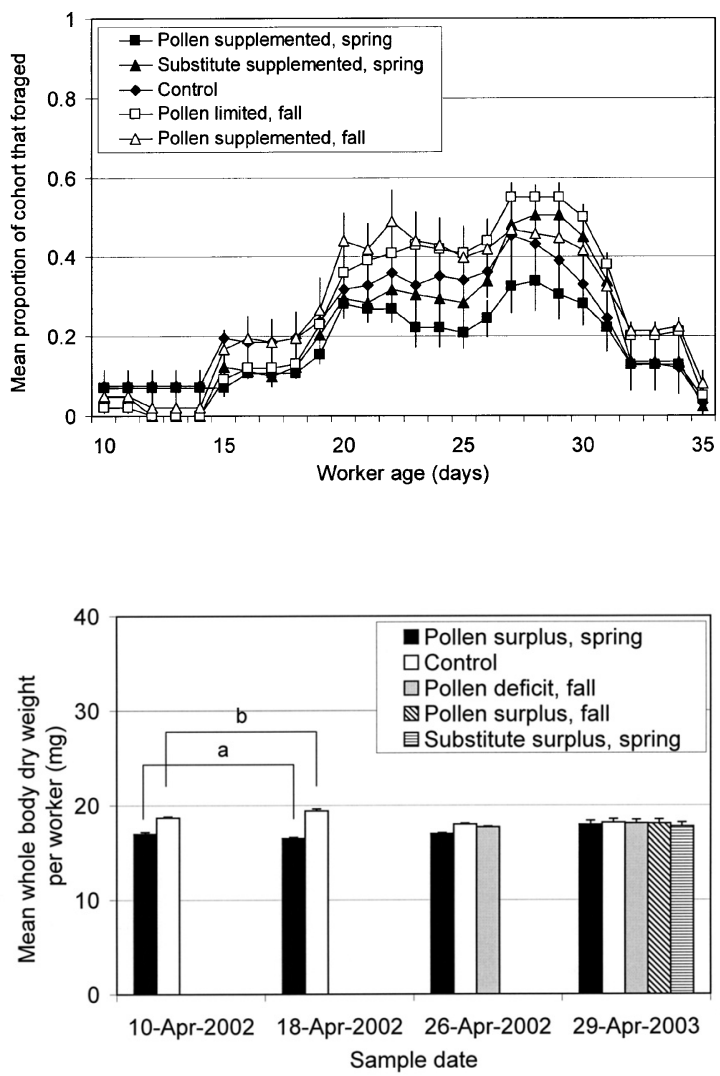

Figure 5. The mean proportion $( \pm$ S.E. $)$ of workers that foraged over time for cohorts of workers reared in pollen-supplemented or pollen-limited colonies during spring 2003. Foraging was monitored at the hive entrance when workers were 10 to 35 days of age ( $\mathrm{N}$ $=5$ colonies per treatment).

Figure 6. The mean whole-body dry weight (+ S.E.) of workers reared in pollensupplemented or pollen-limited colonies and collected at adult emergence during spring 2002 and 2003. Treatment means were separated by Tukey's studentized range test within each year (data were pooled across 10 and 18 April sample dates in 2002). Differences between means are indicated by different letters. In 2002: $\mathrm{N}=7$ pollen-supplemented colonies (both sample dates), $\mathrm{N}=6$ control colonies (both sample dates) and $\mathrm{N}=4$ pollen-limited colonies ( 26 April). In 2003: $\mathrm{N}=5$ colonies per treatment. pollen in the spring joined the foraging workforce.

\subsection{Dry weight and protein content}

\subsubsection{Spring 2002}

There was no difference in the dry weight $(P=0.91)$ or the protein content $(P=0.67)$ of whole worker bodies at emergence between 10 April and 18 April 2002 sample dates, so data were pooled. Dry weights were an average of $2.3 \mathrm{mg}$ lower per worker for individuals reared in colonies with pollen supplements compared to those reared in control colonies (Fig. 6; $P=0.048)$. Protein content was also lower for workers reared in colonies with pollen supplements (mean $6.94 \pm 0.604 \mathrm{mg}$ per bee) compared to workers from control colonies (mean $9.97 \pm 0.800 \mathrm{mg}$ per bee; $P<0.01$ ). When newly emerged workers were sampled later that spring on 26 April, differences were no longer found across treatments for either dry weight (Fig. 6; $P=0.30$ ) or protein content (means ranged from $5.53 \mathrm{mg}$ to $5.82 \mathrm{mg}$ per bee across treatments; $P=0.81$ ).

\subsubsection{Spring 2003}

The whole body dry weight of workers sampled at emergence on 29 April 2003 was not affected by pollen availability during larval rearing (Fig. 6; $P=0.96$ ), nor were differences found in the dry weights of separate parts of the body (head: $P=0.81$; thorax: $P=$ 0.59; abdomen: $P=0.82$ ). Pollen availability during larval development did not influence abdominal protein content (treatment means ranged from 2.90 to $3.26 \mathrm{mg} ; P=0.72$ ), but the protein content of worker heads was affected by pollen-diet regimens $(P=0.02)$. At emergence, workers from colonies that were 
Table II. Correlations between mean worker longevity or the mean proportion of all behaviours performed by cohorts that were related to brood care and other estimates of worker quality for workers reared during spring 2003 ( $N=5$ colonies per treatment). Significant correlations are indicated by asterisks. A BonferroniHolms step-down correction was used to adjust $P$ values for multiple comparisons against mean worker longevity and brood-care behaviour.

\begin{tabular}{lcccc}
\hline \multirow{2}{*}{ Correlated estimate } & \multicolumn{2}{c}{ Mean worker longevity } & \multicolumn{2}{c}{ Mean brood-care behaviour } \\
\cline { 2 - 5 } & r value & $P$ value & r value & $P$ value \\
\hline Mean forager lifespan per worker (days) & 0.69 & $<0.01^{*}$ & -0.50 & $0.04^{*}$ \\
Mean head protein content $(\mu \mathrm{g})$ & -0.17 & 0.41 & 0.45 & 0.09 \\
Mean whole-body dry weight $(\mathrm{mg})$ & 0.34 & 0.20 & -0.33 & 0.22 \\
Mean longevity (days) & - & - & -0.07 & 0.73 \\
\hline
\end{tabular}

${ }^{\text {a }}$ Includes all workers in cohort, including workers that were not observed foraging.

supplemented with pollen during the spring had $0.64 \pm 0.029 \mathrm{mg}$ of protein in their heads compared to $0.51 \mathrm{mg}$ to $0.52 \mathrm{mg}( \pm 0.029)$ of protein in the heads of workers reared by colonies in other treatment groups.

\subsection{Correlations between variables}

In 2003, worker longevity was positively correlated with increased forager lifespan, but had no relationship with brood-care behaviour, head protein content or whole body dry weight (Tab. II). Brood-care behaviour was inversely related to forager lifespan (Tab. II). Dry weights and protein contents of worker heads at emergence were not correlated with brood-care behaviour later in life (Tab. II).

\section{DISCUSSION}

This research shows that the quality of spring-reared workers is strongly influenced by the availability of pollen in colonies during larval development, in addition to the simultaneous adjustments that were made to the quantity of workers that were produced during the same springs (Mattila and Otis, 2006). The stimulatory effect of additional pollen (or a pollen substitute) on brood rearing in the colonies examined in this study was consistent across years (Mattila and Otis, 2006), but this was not accompanied by regular patterns in the behaviour and physiology of the workers themselves over the same period. This suggests that the aspects of worker quality that we evaluated were controlled in part by the nutritional state of colonies when workers were reared, but also by environmental factors that were beyond the control of this study. It is likely that these factors interacted with the effects of pollen availability on workers and that their prevalence from year to year had a dramatic influence on the nature of the response of workers to the conditions of pollen availability under which they were reared.

The survivorship curves of workers in both years provide insight into the possible reasons for these differences. In 2003, the benefits of pollen supplements and the costs of limited pollen were not reflected in worker survival in the same way that they were in 2002. In 2002 , it appears that a surplus of pollen during larval rearing allowed workers to achieve a higher rate of survival than workers from control or pollen-limited colonies were capable of achieving, possibly because extreme nutritional deprivation of the latter groups during larval rearing could not be overcome after adult emergence and introduction into the observation hive. In 2003, all workers had similar rates of survival, which suggests that conditions of deprivation during larval rearing were compensated for by workers as adults. Presumably, the nutrients required for this compensation were obtained from supplies in the observation hive and/or from resources available in the environment during the spring or the preceding fall (more pollen was collected from trapped colonies in 2003 compared to 2002), which moderated the influence of larval 
rearing conditions on the longevity of workers in 2003. Other moderating factors may include the availability of floral resources during the spring or the influence of spring weather on the opportunities that workers had to forage. Weather records during these years support this explanation. The spring in 2002 was cooler for extended periods compared to 2003 and foraging during 2002 was often restricted (Mattila and Otis, 2006). Spring foraging conditions improved substantially in 2003, and the influence of the pollen-diet manipulations in colonies on worker survival diminished under these circumstances.

Faced with a similar nursing load in the common environment of the observation hive in 2003, workers reared in pollensupplemented colonies performed significantly better as nurses, although associated increases in longevity were not found. These workers also spent less time patrolling or resting idly in the colony and participated in foraging less often. This means that workers reared in colonies that had pollen supplements tended to focus more on in-hive tasks rather than outside tasks as adults. Significant negative correlations between brood-care behaviour and forager lifespan suggest that worker investment in one activity increased as the other decreased. The factors that influenced these differences are not clear, but it is apparent that they can impose large changes in the behaviour of workers as adults in concert with the effects of pollen supply on worker traits.

In 2003, workers reared in colonies supplemented with pollen during the spring had higher levels of protein in their heads at emergence and also tended brood longer than workers reared in colonies that were not supplemented during the spring. Supplementation with a pollen substitute did not result in significantly higher protein levels at emergence, but these workers were also observed caring for brood longer than workers from less pollen-rich colonies. These results suggest the possibility that higher levels of nutritional investment in workers in the larval stage could ultimately impact the fate of workers as adults in division of labour within the colony. It also implies that these reserves contribute to the lifetime ability of workers to nurse. Work- ers utilize protein reserves in their bodies to maintain brood rearing and the exhaustion of these stores is what limits their ability to nurse (Haydak, 1935; Maurizio, 1950, 1954). An additional reserve of protein at adult emergence may provide enough supplementary nutrients to prolong the duration of brood care, even though workers had equal opportunity to consume pollen as adults to support their broodrearing activities. It is difficult to confirm these hypothetical explanations because in 2002 workers that were long-lived (implying that they spent more time nursing or performing other in-hive tasks) also had lower protein levels at emergence. The differences in the relationship between protein content and longevity between years are intuitively illogical. They also contradict the findings of previous authors who observed that increased access to pollen or protein resources was positively correlated with worker longevity (DeGroot, 1953; Maurizio, 1954; 1959; Eischen et al., 1982; Kunert and Crailsheim, 1988). The reasons for this anomaly are not revealed by these data, but it is a clear and interesting pattern.

In 2002, mortality increased significantly for workers from pollen-limited and control colonies at the age where workers would be expected to initiate foraging (Lindauer, 1953; Winston, 1987). It is probable that an increase in longevity for workers reared in pollensupplemented colonies in 2002 was due to a delay in the onset of foraging for these workers, potentially because of an increase in the amount of time devoted to in-hive tasks such as nursing. This inference is based on the conclusions of Maurizio (1950, 1954, 1959), who found that worker longevity was primarily determined by the length of time workers were capable of rearing brood during the early part of their life, mediated by the availability of pollen. Unfortunately, we do not have the data to confirm this hypothesis and it is undermined in part by the conflicting results obtained in 2003. In this year, there was no relationship between nursing activity and worker longevity, but rather, workers from colonies that participated in foraging in greater numbers also lived longer. Additionally, it was intriguing that the ability of workers to function as foragers was inversely correlated with the amount 
of time they spent caring for brood. Neither of these results have been demonstrated previously and both contradict earlier work that showed that the energy devoted to foraging is static for all workers and that longevity is determined by the length of the in-hive period (Maurizio, 1954, 1959; Fukuda and Sekiguchi, 1966; Neukirch, 1982), as well as our own hypothesis to explain increases in the longevity of workers reared in pollen-rich colonies in 2002.

In 2003, we observed that once foraging was initiated, foragers spent the same number of days in the field, but the likelihood that a worker would eventually join the foraging workforce was inversely related to their participation in physiologically demanding in-hive tasks such as brood care. Does this mean that workers that failed to join the foraging population simply died from exhaustion in the colony in the spring of 2003? Very few workers die within the nest and most die on foraging trips (Gary, 1960). Therefore, it is likely that workers reared in pollen-supplemented colonies exited the colony without detection and died soon after foraging was initiated. The reasons why extensive brood rearing activity would influence the duration of foraging later in life are not clear. There may be a relationship between the depletion of reserves during nursing and the subsequent ability of a worker to function effectively as a forager, as is suggested by these data, but that relationship requires further clarification. It is an interesting question because it is contrary to what would be expected if all workers had a fixed amount of energy allocated to foraging (Neukirch, 1982) or if they experienced a constant probability of death as they foraged (Visscher and Dukas, 1997).

Other authors have suggested that larval malnutrition can result in the production of undersized workers under lab conditions or in small experimental colonies (Alpatov, 1929; Fyg, 1959; Jay, 1964; Eischen et al., 1982; Daly et al., 1995). We have also observed unusually small workers in colonies in early spring and attributed it to the same phenomenon. When this was investigated systematically, there was no evidence to support the hypothesis that pollen-stressed colonies regu- larly produce smaller workers. This was especially true in the spring of 2002 when workers from pollen-supplemented colonies actually had lower dry weights than workers from control colonies, although differences disappeared in workers sampled later in April, after pollen became more readily available from the environment during rearing. This suggests that colonies return to more uniform production of workers once environmental conditions stabilize.

Ultimately, the investment in workers during larval rearing, best reflected by worker dry weight and protein content at adult emergence, is relatively stable in contrast to measures of the performance of workers as adults, which was greatly influenced by differences in environmental influences over a worker's lifetime. We return to the resolution of our initial question: does the availability of pollen in colonies during larval development affect the quality of workers that are produced? The answer is yes, but several caveats are required. The nature of the effect of pollen supply on worker quality is mediated by other environmental influences. It is likely that the differences in worker quality that were observed between years point to subtle, but as of yet unidentified, variables that may be unique to colonies under different environmental circumstances, and that interact with colony nutritional status to have considerable effects on bees. This study highlights the striking effect that larval nutrition can exert on bees during this limited, but crucial, period in the life of a colony.

\section{ACKNOWLEDGEMENTS}

We thank staff apiarist P. Kelly and students J. Armstrong, H. Bettger, D. Cutler, S. Jandricic, S. Leckie, B. Locke, N. McKenzie and R. Wosoloski for assistance with data collection and processing. We are also grateful to N.A. Buck, D. Gibo, J.M. Schmidt, G. Umphrey and D.E. Wheeler for the expertise that they contributed to this work. Two anonymous reviewers provided valuable comments on the manuscript that improved its final form. This study was supported by grants from the Canadian Bee Research Fund, the Eastern Apicultural Society and the Natural Sciences and Engineering 
Research Council of Canada (a P.G.S.-A and C.G.S. to H.R.M. and a Discovery Grant to G.W.O.).

Résumé - Effets de la disponibilité en pollen au cours du développement larvaire sur le comportement et la physiologie des ouvrières d'abeilles élevées au printemps. Les colonies d'abeilles (Apis mellifera L.) reconstruisant leurs populations au printemps, les ouvrières utilisent le pollen stocké et des occasions sporadiques de butinage pour fournir la nourriture nécessaire au développement des larves. Sur la période 2002-2004 nos études antérieures ont documenté les ajustements faits par les colonies en ce qui concerne la quantité d'ouvrières produites au printemps en réponse à l'offre de pollen. Mais les effets sur la qualité des ouvrières produites durant cette période n'ont pas été étudiés. L'étude visait à connaître l'influence de la disponibilité en pollen sur le comportement et la physiologie des ouvrières produites au cours des printemps 2002 et 2003. Certaines colonies $(\mathrm{P}+)$ ont été supplémentées en pollen durant le printemps (avec du pollen ou un succédané) ou durant l'automne précédent (avec du pollen seulement). D'autres colonies $(\mathrm{P}-)$ ont eu leur apport en pollen limité par la présence de trappes à pollen mises en place à l'automne avant l'hivernage. Les colonies que l'on a laissé stocker et utiliser le pollen naturellement ont servi de témoins. Les ouvrières élevées dans toutes les colonies tests ont été transférées après leur émergence dans une même ruche d'observation. Des ouvrières élevées au printemps ont aussi été prélevées dans les colonies à leur émergence pour déterminer les effets de la fourniture de pollen sur le poids sec des ouvrières et sur leur teneur en protéines. En 2002 les ouvrières élevées dans les colonies $\mathrm{P}+$ ont vécu significativement plus longtemps que celles des colonies témoins ou des colonies P-. En 2003 les différences concernant la longévité ont été inversées (Fig. 1). On n'a pas observé de différences concernant le poids sec cette année là, mais les teneurs en protéines des têtes étaient plus élevées chez les ouvrières élevées dans les colonies $\mathrm{P}+$, ce qui peut être lié au meilleur développement des glandes hypopharyngiennes plus tard au cours de la vie. Cela expliquerait pourquoi les ouvrières élevées dans les colonies $\mathrm{P}+$ ont passé deux fois plus de temps à s'occuper du couvain, moins de temps à garder la ruche d'observation et moins de temps à rester oisives sur le rayon par rapport aux ouvrières des colonies $\mathrm{P}-$ ou témoins. Les ouvrières des colonies $\mathrm{P}+$ ont été moins sujettes à démarrer le butinage que celles des autres traitements (Tab. I). Il est clair que la disponibilité en pollen des colonies durant la période de production des ouvrières de printemps a eu un effet sur le comportement et la physiologie de ces ouvrières une fois adultes, bien que les différences aient varié avec les années. Les grandes différences dans les caractéristiques des ouvrières d'un printemps à l'autre indiquent que les performances des ouvrières sont affectées par les facteurs du milieu, qui n'étaient pas contrôlés dans cette étude, en sus de l'influence exercée par la disponibilité en pollen des colonies au cours du développement larvaire.

\section{Apis mellifera / pollen / division du travail / qua- lité des ouvrières}

Zusammenfassung - Der Einfluss der Verfügbarkeit von Pollen während der larvalen Entwicklung auf das Verhalten und die Physiologie von im Frühjahr aufgezogenen Arbeiterinnen. Beim Wiederaufbau der Population der Bienenvölker im Frühjahr nutzen Arbeiterinnen den eingelagerten Pollen und sporadische Trachtmöglichkeiten als Futter für die Brutaufzucht. Während den 3 Jahren von 2002 bis 2004 wurde bei früheren Studien die Anpassung der Völker in Bezug auf die Anzahl erzeugter Arbeiterinnen in Abhängigkeit von der zur Verfügung stehenden Pollenmenge dokumentiert. Die damit verbundenen Effekte auf die in dieser Zeit erzeugten Arbeiterinnen wurden bisher nicht beschrieben. In diesen Versuchen wurde der Einfluss der Verfügbarkeit von Pollen auf Verhalten und Physiologie der Arbeiterinnen untersucht, die im Frühjahr 2002 und 2003 produziert wurden. Der Pollenvorrat der Völker wurde während des Frühjahrs ergänzt durch Pollen oder Pollenersatz oder bereits im vorhergehenden Herbst, dann aber nur mit Pollen. Die Pollenmenge für das Frühjahr wurde durch Pollenfallen im Herbst vor der Einwinterung reguliert. Völker, die Pollen im natürlichen Umfang lagern und nutzen konnten, wurden als Kontrollen eingesetzt. Arbeiterinnen, die in Versuchsvölkern aufgezogen wurden, wurden in beiden Jahren nach dem Schlupf in ein gemeinsames Beobachtungsvolk eingesetzt. Dort wurden Unterschiede in der Lebensdauer und in der Arbeitsteilung überwacht. Außerdem wurden im Frühling aufgezogene Arbeiterinnen beim Schlupf aus Völkern abgefangen, um den Einfluss der Pollenversorgung auf Trockengewicht und Eiweißgehalt zu bestimmen. Im Jahr 2002 lebten die Arbeiterinnen aus Völkern mit Pollenersatz signifikant länger als Arbeiterinnen der Kontrollvölker bzw. der Völker mit begrenzter Pollenmenge, obwohl bei ihnen Trockengewichte und Eiweißgehalt beim Schlupf geringer waren. Im Jahr 2003 waren die Unterschiede zwischen Arbeiterinnen aus behandelten Völkern genau umgekehrt und Arbeiterinnen, aufgezogen in Völkern mit Pollenersatz, lebten kürzer als Arbeiterinnen, aufgezogen in Völkern mit begrenzter Pollenmenge. Im Trockengewicht ergab sich in diesem Jahr kein Unterschied zwischen den Versuchen, aber die Eiweißmenge des Kopfes war höher bei Völkern mit Ersatzpollen. Das mag mit einer nachfolgenden besseren Entwicklung der Hypopharynxdrüsen zusammenhängen. Das würde auch erklären, warum Arbeiterinnen aufgezogen in Völkern mit Pollenersatz 
im Beobachtungsvolk doppelt soviel Zeit mit Brutpflege, weniger Zeit mit Patroullieren und weniger Zeit mit Nichtstun verbrachten als Arbeiterinnen von Völkern mit natürlicher oder begrenzter Pollenmenge. Arbeiterinnen, aufgezogen in Völkern mit Pollenersatz, haben seltener Trachtflüge initiiert als Arbeiterinnen aus anders behandelten Völkern. Es ist klar, dass die Verfügbarkeit von Pollen in Völkern, die Frühjahrsbienen erzeugen, einen Einfluss auf das Verhalten und die Physiologie dieser Arbeiterinnen im Adultstadium hatte, obwohl das Muster über die Jahre nicht konsistent blieb. Große Unterschiede zwischen den Frühjahren in den Eigenschaften der Arbeiterinnen deuten darauf hin, dass die Leistung der Arbeiterinnen während der Aufzucht zusätzlich zur Verfügbarkeit des Pollens im Volk durch Umweltfaktoren beeinflusst werden, die in diesen Versuchen nicht kontrolliert wurden.

Apis mellifera / Pollen / Brutpflege/ Arbeitsteilung / Qualität der Arbeiterinnen

\section{REFERENCES}

Alpatov W.W. (1929) Biometrical studies on variation and races of the honey bee (Apis mellifera L.), Q. Rev. Biol. 4, 1-58.

Amdam G.V., Omholt S.W. (2002) The regulatory anatomy of honeybee lifespan, J. Theor. Biol. 216, 209-228.

Calderone N.W., Page R.E. Jr. (1992) Effects of interactions among genotypically diverse nestmates on task specialization by foraging honey bees (Apis mellifera), Behav. Ecol. Sociobiol. 30, 219-226.

Crailsheim K. (1990) The protein balance of the honey bee worker, Apidologie 21, 417-429.

Daly H.V., Danka R.G., Hoelmer K., Rinderer T.E., Buco S.M. (1995) Honey bee morphometrics: linearity of variables with respect to body size and classification tested with European worker bees reared by varying ratios of nurse bees, J. Apic. Res. 34, 129-145.

DeGroot A.P. (1953) Protein and amino acid requirements of the honeybee (Apis mellifica L.), Physiol. Comp. Oecol. 3, 197-285.

Dreller C., Page R.E. Jr. (1999) Genetic, developmental, and environmental determinants of honey bee foraging behaviour, in: Detrain C., Deneubourg J.L., Pasteels J.M. (Eds.), Information processing in social insects, Birkhäuser Verlag, Berlin, Germany, pp. 187-202.

Duff S.R., Furgala B. (1986) Pollen trapping honey bee colonies in Minnesota: Part II: Effect on foraging activity, honey production, honey moisture content, and nitrogen content of adult workers, Am. Bee J. 126, 755-758.
Dustmann J.H., von der Ohe W. (1988) Einfluß von Kälteeinbrüchen auf die Frühjahrsentwicklung von Bienenvölkern (Apis mellifera L.), Apidologie 19, 245-254.

Eischen F.A., Rothenbuhler W.C., Kulinĉević J.M. (1982) Length of life and dry weight of worker honeybees reared in colonies with different worker-larva ratios, J. Apic. Res. 21, 19-25.

Farrar C.L. (1934) Bees must have pollen, Glean. Bee Cult. 62, 276-278.

Farrar C.L. (1936) Influence of pollen reserves on the surviving populations of over-wintered colonies, Am. Bee J. 76, 452-454.

Fluri P., Lüscher M., Wille H., Gerig L. (1982) Changes in weight of the pharyngeal gland and haemolymph titres of juvenile hormone, protein and vitellogenin in worker honey bees, J. Insect Physiol. 28, 61-68.

Free J.B. (1961) Hypopharyngeal gland development and division of labour in honey bee (Apis mellifera L.) colonies, Proc. R. Entomol. Soc. A 36, 5-8.

Fukuda H., Sekiguchi K. (1966) Seasonal change of the honeybee worker longevity in Sapporo, North Japan, with notes on some factors affecting the life-span, Jpn J. Ecol. 16, 206-212.

Fyg W. (1959) Normal and abnormal development in the honeybee, Bee World 40, 57-66, 85-96.

Gary N.E. (1960) A trap to quantitatively recover dead and abnormal honey bees from the hive, J. Econ. Entomol. 53, 782-785.

Haydak M.H. (1935) Brood rearing by honeybees confined to a pure carbohydrate diet, J. Econ. Entomol. 28, 657-660.

Hellmich R.L., Kulinĉević J.M., Rothenbuhler W.C. (1985) Selection for high and low pollen-hoarding honey bees, J. Hered. 76, 155-158.

Herbert Jr. E.W. (1992) Honey bee nutrition, in: Graham J.M. (Ed.), The hive and the honey bee, Dadant and Sons, Hamilton, Illinois, pp. 197-233.

Jay S.C. (1964) Starvation studies of larval honey bees, Can. J. Zool. 42, 455-462.

Kolmes S.A. (1984) A quantitative comparison of observational methodologies for studies of worker honeybees, J. Apic. Res. 23, 189-198.

Kulinĉević J.M., Rothenbuhler W.C., Rinderer T.E. (1983) Disappearing disease - II. Effects of certain protein sources on brood rearing and length of life in the honey bee under laboratory conditions, Am. Bee J. 123, 50-53.

Kunert K., Crailsheim K. (1988) Seasonal changes in carbohydrate, lipid and protein content in emerging worker honeybees and their mortality, J. Apic. Res. 27, 13-21.

Levin M.D., Haydak M.H. (1951) Seasonal variation in weight and ovarian development in the worker honeybee, J. Econ. Entomol. 44, 54-57. 
Lindauer M. (1953) Division of labour in the honeybee colony, Bee World 34, 63-90.

Mattila H.R., Otis G.W. (2006) Influence of pollen diet in spring on development of honey bee (Hymenoptera: Apidae) colonies, J. Econ. Entomol. 99, 604-613.

Mattila H.R., Harris J.L., Otis G.W. (2001) Timing of production of winter bees in honey bee (Apis mellifera) colonies, Insectes Soc. 48, 88-93.

Maurizio A. (1950) The influence of pollen feeding and brood rearing on the length of life and physiological condition of the honeybee: preliminary report, Bee World 31, 9-12.

Maurizio A. (1954) Pollenernährung und Lebensvorgänge bei der Honigbiene (Apis mellifica L.), Landwirt. Jahrb. Schweiz 62, 115-182.

Maurizio A. (1959) Factors influencing the lifespan of bees, in: Wolstenholme G.E.W., O'Connor M. (Eds.), Proc. Ciba Foundation, Symp. on the lifespan of animals, Churchill, London, pp. 231-243.
Neukirch A. (1982) Dependence of the life span of the honeybee (Apis mellifera) upon flight performance and energy consumption, J. Comp. Physiol. B 146, 35-40.

Schmickl T., Crailsheim K. (2001) Cannibalism and early capping: strategy of honeybee colonies in times of experimental pollen shortages, J. Comp. Physiol. A 187, 541-547.

SAS Institute (2004) SAS/STAT 9.1 user's guide, SAS Institute, Inc., Cary, North Carolina.

Visscher P.K., Dukas R. (1997) Survivorship of foraging honey bees, Insectes Soc. 44, 1-5.

Wang D.-I., Moeller F.E. (1970) The division of labor and queen attendance behavior of Nosemainfected worker honey bees, J. Econ. Entomol. 63, 1539-1541.

Winston M.L. (1987) The biology of the honey bee, Harvard University Press, Cambridge, Massachusetts. 